\title{
ДОДАТОК 4
}

\section{DEAIIITHA $10 x$ IALOPAMA 2008}

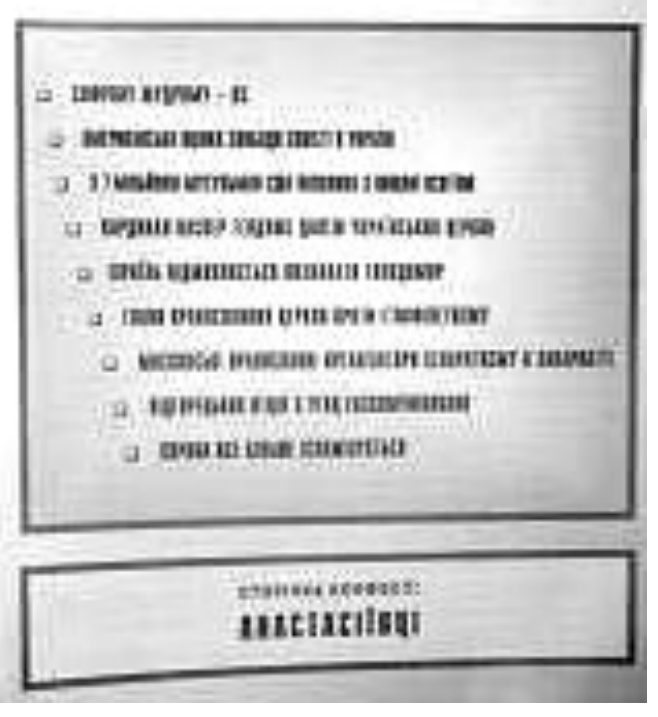

“Релігійна панорама" - це передплатний інформаційно-аналітичний журнал, який академічні релігієзнавці видають для колег, викладачів-релігієзнавців, студентів, що вивчають релігієзнавчі дисципліни, для всіх, хто цікавиться релігійним життям та релігійно-духовною

проблематикою, відповідними подіями в Україні та світі, новинками релігієзнавчих публікацій, релігієзнавчими конференціями та релігієзнавчою освітою.

Передплатити часопис можна в поштових відділеннях. Передплатний індекс: 21963

В редакції наявні деякі числа минулих років (довідки за тел. (044) 279-04-18).

Бюлетень
Української Асоціації релігієзнавців

і Відділення релігієзнавства

імені Г.С. Сковороди НАН України

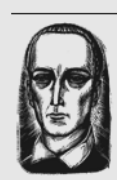

Українське релігієзнавство
Бюлетень «Українське релігісзнавство» - науковий релігієзнавчий квартальник, який видруковують Відділення релігієзнавства ІФ НАНУ та Українська Асоціація релігієзнавців. Бюлетень затверджений ВАК України як періодичне наукове фахове видання за профілем «філософські науки», «історичні науки» та «соціологічні науки». Видається щоквартально 31996 р. Свідоцтво про державну реєстрацію КВ № 2057 від 16 липня 1996 p.

Тел.: (044) 279-48-12 - головний редактор, (044) 279-04-18 - відповідальний секретар; E-mail: uar-press@online.ua 